\title{
Environmental Engineering for Stopping Viruses Pandemics
}

\author{
Djamel Ghernaout ${ }^{1,2 *}$, Noureddine Elboughdiri1,3 \\ ${ }^{1}$ Chemical Engineering Department, College of Engineering, University of Ha'il, Ha'il, KSA \\ ${ }^{2}$ Chemical Engineering Department, Faculty of Engineering, University of Blida, Blida, Algeria \\ ${ }^{3}$ Département de Génie Chimique de Procédés, Laboratoire Modélisation, Analyse, et Commande des systèmes, Ecole Nationale \\ d’Ingénieurs de Gabès (ENIG), Rue Omar Ibn-Elkhattab, Gabès, Tunisia \\ Email: *djamel_andalus@hotmail.com
}

How to cite this paper: Ghernaout, D. and Elboughdiri, N. (2020) Environmental Engineering for Stopping Viruses Pandemics. Open Access Library Journal, 7: e6299. https://doi.org/10.4236/oalib.1106299

Received: April 4, 2020

Accepted: April 19, 2020

Published: April 22, 2020

Copyright $\odot 2020$ by author(s) and Open Access Library Inc.

This work is licensed under the Creative Commons Attribution International License (CC BY 4.0).

http://creativecommons.org/licenses/by/4.0/

\begin{abstract}
A huge number of investigations on the ecological sources, fate, and transport of viruses have been dedicated to non-enveloped viruses such as norovirus and enteroviruses. However, more recent global outbreaks of viral diseases have been provoked by enveloped viruses comprising viruses from the Coronavirus family (SARS, MERS, COVID-19). Enveloped viruses have a lipid membrane encircling their protein capsid and genome. SARS-CoV-2 will surely not be the ultimate fresh virus to jut and badly terrorize worldwide public health and life. Scientists and funding agencies have a trend to concentrate largely on a particular virus throughout its eruption; however, then advance on to different themes when the eruption calms. Considering the historical contributions from environmental engineering, and the huge dares that emerge, environmental science and engineering specialists have to adopt a larger, long-term, and more quantitative strategy to comprehending viruses that are diffusing through nature. Identical to the manner by which chemical contaminants are handled in the environment, the particular properties that control transport and demobilization of enveloped viruses in solutions, on surfaces, and in the air must be understood. Besides, the fashion by which ecological parameters form likely virus transmission mechanisms should be comprehended. Thereby, despite the identity of the enveloped virus that provokes the following main eruption, more sophisticated detailing of its endurance and guidance on how to reduce its diffusion may be given.
\end{abstract}

\section{Subject Areas}

Chemical Engineering \& Technology, Infectious Diseases, Public Health

\section{Keywords}

Coronaviruses, COVID-19, Wastewater-Based Epidemiology (WBE), 
Particulate Matters (PMs), Wastewater Treatment Plant, Disinfection

\section{Introduction}

A huge number of investigations on the ecological sources, fate, and transport of viruses have been dedicated to non-enveloped viruses such as norovirus and enteroviruses [1] [2]. However, more recent global outbreaks of viral diseases have been provoked by enveloped viruses comprising viruses from the Coronavirus family (SARS, MERS, COVID-19). Enveloped viruses have a lipid membrane encircling their protein capsid and genome. Shortage of information on the occurrence of infective enveloped viruses in human waste, the ecological fate and diffusion of enveloped viruses, best applications to disinfect surfaces and water, wash contaminated body parts, and treat wastewater and feces to removal enveloped viruses, has hampered outbreak response. Investigating into the ecological persistence and pathways of transmission of SARS, MERS, and COVID-19 becomes more difficult via protection worries of dealing with high-risk viruses. Thus, there is a restricted direct study ready on the ecological perseverance of viruses in the Coronavirus family. The plurality of the study has been performed on enveloped "surrogate" viruses. Recently, ES\&T and ES\&T Letters [1] published a set of investigations furnishing an understanding of the present situation of facts on the perseverance and conduct of enveloped viruses in nature. Much of the study has been realized employing surrogate enveloped viruses, which possess identical characteristics to the human enveloped viruses presently of acute attention [1].

This work furnishes worthy details and understandings on the likely ecological destiny and spread of enveloped viruses. Such data comprise demobilization routes that could happen throughout frequent water disinfection techniques, the possibility for secondary transmission of the virus through aerosolization from wastewater and further human exposure through inhalation, the performance of the cleanup of virus-contaminated surfaces, and the behavior of land-filled infectious waste.

\section{Spread of COVID-19: Contribution of Ecological Parameters}

From the beginning of this $21^{\text {st }}$ century, the germination of viral epidemics constitutes huge menaces to human health and life [3]. Such contagious viruses have been classified as hemorrhagic fever viruses (Lassa, Ebola), new coronaviruses comprising severe acute respiratory syndrome $\mathrm{CoV}$ (SARS-CoV), Middle-East respiratory syndrome (MERS-CoV), and greatly pathogenic influenza. As a category of enveloped, positive-sense single-stranded RNA virus, coronaviruses (CoVs) provoke numerous diseases in human beings. They are subdivided into four groups: Alphacoronavirus, Betacoronavirus $(\beta \mathrm{CoV})$, Gammacoronavirus, 
and Deltacoronavirus. Two new $\beta \mathrm{CoVs}$, severe acute respiratory syndrome $\mathrm{CoV}$ (SARS-CoV) and Middle-East respiratory syndrome CoV (MERS-CoV), have lately surfaced and could cause an elevated death-rate. The actual eruption of fresh coronavirus COVID-19 (HCoV-19 or SARS-CoV-2) has pushed the World Health Organization (WHO) to announce such eruption a universal pandemic. By March 31, 2020, infected cases had reached 719,758 and a total of 33,673 deaths in the world have been reported by the WHO [4].

Comparable to the SARS-CoV, symptoms of COVID-19 infection at the onset of the illness comprise fever, myalgia, fatigue, and cough, and more than half of patients developed dyspnoea [3]. Numerous patients had radiographic ground-glass lung alterations, and lower than average circulating lymphocyte and platelet populations. Until March 15, 2020 [5], the global deaths attained 5746 , and the fatality rate was evaluated as $3.7 \%$ for COVID-19 virus [4], which was lower than that of SARS-CoV (10\%) or MERS-CoV (37\%) [5]. The main dare of the coronavirus family and identical infectious agents is that no efficient drugs or vaccines are ready, and it may take several months for research and development [3].

Human-to-human transmission of COVID-19 happens if individuals are in the incubation stage or showing symptoms; however, some individuals stay contagious whilst staying asymptomatic (superspreaders). Transmission is thought to take place via touching infected surfaces (skin-to-skin, touching infected inanimate objects) then mediating the COVID-19 infection through the mouth, nose, or eyes. Transmission could as well be via inhalation of the exhaled virus in respiratory droplets. Infectious viruses, comprising coronavirus, could survive for long periods outside of its host organism [6]. COVID-19 virus is thought to survive for many hours on surfaces like aluminum, sterile sponges, or latex surgical gloves, augmenting the hazard for transmission via touch. Transmission via the inhalation of small exhaled respiratory droplets could happen since the aerosol droplets stay airborne for prolonged periods, mediating long-range human-to-human transmission via air movement [3].

Fecal transmission pathways have as well to be taken into account since the COVID-19 virus has been positively detected in stool samples of infected patients. It was proved that SARS-CoV could survival in stool samples for 4 days [6]. Scientists mentioned that coronavirus can stay infectious in water and sewage for days to weeks [7]. At ambient temperature, in pure water or pasteurized settled sewage, the time requested for a $99 \%$ reduction of virus infectivity was found to be numerous days [7]. This increases one more possible transmission pathway if the quality of personal hygiene is poor. Infected stools in wastewater could form further transmission pathways by the formation of virus-laden aerosols throughout wastewater flushing. A polluted faulty sewage system in a high-rise housing estate in Hong Kong in 2003 was related to the SARS eruption of a great number of residents living in the surrounding buildings [8]. Consequently, the contribution of the aerosol from polluted sewage in the transmission of COVID-19 has to be monitored [3]. 
An additional transmission route can be through airborne dust. Microorganisms in airborne particulate matters (PMs) or dust are related to infectious diseases [9]. Substandard nationwide air contamination is recurrent in many developing countries, and the contribution of air PM and dust in the transmission of COVID-19 infection stays unexamined. Inhalation of virus-laden fine particles can transport the virus into deeper alveolar and tracheobronchial regions, which can elevate the hazard of infective transmission. Adsorption of the COVID-19 virus on airborne dust and PM can as well participate in the long-range transport of the virus. Thus, researches on adsorption, survival, and behavior of the COVID-19 virus inside the surface of PM are requested to assist to comprehend the function of air PM contamination in COVID-19 transmission [3].

The degree to which the COVID-19 virus causes respiratory stress in infected individuals may as well be touched via the level to which an individual's respiratory system is previously damaged. The elevated degrees of PM pollution in China could augment the vulnerability of the population to additional grave symptoms and respiratory complications of the disease. Further, oxidant pollutants in the air could damage the immune function and weaken the performance of the lungs to remove the virus from the lungs. The concomitant inhalation of chemical contaminants in PM beside the COVID-19 virus can as well aggravate the degree of COVID-19 infection. Pro-inflammation, injury, and fibrosis from inhaled PM integrated with an immune response or cytokine storm induced by COVID-19 infection can elevate the infection severity. Bigger numbers of patients showing more grave infection symptoms also augmented the danger of elevated transmission potential. Thus, the pathways underlying the effect and modulation of air pollution on COVID-19 severity and onward transmission justify more research [3].

Considered jointly, the subsistence of the COVID-19 virus in numerous natural media, comprising water, PM, dust, and sewage below a collection of ecological factors reasons methodical research at once. Degrees of infectious virus in ecological samples can be small, needing high-sensitivity procedures for an accurate measure of COVID-19 virus to be improved. In the future, such fresh coronavirus could as well begin to be a seasonal infectious virus. The manifestation, endurance, and comportment of COVID-19 virus in natural fields must be controlled, needing the improvement of high-throughput, automatic methods for virus observing. For now, to decrease the risk of infection, it is vital to present handy technologies for large-scale disinfection treatment of the COVID-19 virus in various ecosystems [3].

\section{Following COVID-19 Sources with Wastewater-Based Epidemiology}

Numerous clinical cases have observed that many carriers of the virus could be asymptomatic, with no fever, and no, or only slight symptoms of infection [10]. 
Without the possibility to show such asymptomatic patients readily and efficiently, such unwary carriers possess the possibility to augment the danger of disease transmission if no prompt efficient quarantine actions are executed. Thus, to discover obscure COVID-19 sources, rapid and exact examination of potential virus carriers and diagnosis of asymptomatic patients are a key stage for intervention and prevention at the premature point.

It stays a greatly defying logistical practice for medical professionals to realistically and efficiently sieve suspected infectious cases from individual households [10]. This huge task is time-consuming and labor-intensive and is held back via the accessibility of examination techniques at this very perilous period. Nevertheless, a substitutional procedure employing wastewater-based epidemiology (WBE) could furnish an efficient method to anticipate the likely diffusion of the infection through examination for infectious agents in wastewater, which has been confirmed as an efficient manner to detect illicit drugs, and acquire details on health, disease, and pathogens [11].

Feces and urine from disease carriers in the community will hold numerous biomarkers that could come into the sewer system. Live SARS-CoV-2 was isolated from the feces and urine of infected people that would then come into the wastewater treatment system [12]. SARS-CoV-2 could typically endure for up to numerous days in a convenient medium after leaving the human body [10]. Thus, it is possible that the analysis of SARS-CoV-2 in community wastewater can follow COVID-19 sources via sewage pipe networks and decide if there are probable SARS-CoV-2 carriers in some local regions. If SARS-CoV-2 could be observed in the community at the premature phase via WBE, an efficacious intervention could be taken as precocious as conceivable to limit the motions of that local population, operating to reduce the pathogen diffusion and menace to public health.

Employing a WBE strategy in expanding a premature cautionary system and following an efficacious intervention system will need a fast analytical method for the on-site revelation of viruses at the wastewater collection point. Presently, the most direct manner for the detection of SARS-CoV-2 is a nucleic acid-based polymerase chain reaction (PCR) check, which is as well a method for affirmation of COVID-19 patients in China. Even if PCR possesses elevated responsiveness and specificity, needs for intricate sample processing in the laboratory, skilled personnel, and an extended time of data treatment and analysis $(4-6 \mathrm{~h})$ are not favorable to real-time and efficient surveillance of samples on-site. Thus, it remains decisive to suggest performant transportable and robust analytical instruments to exactly and rapidly detect low-level SARS-CoV-2 sources via WBE to affirm such suspected cases and garble asymptomatic infected cases without centralized laboratories [10].

Paper analytical gadgets have come out as strong instruments for the quick identification of pathogens and the establishment of infection transmission [13]. The paper-founded apparatus is a small analytical instrument with various func- 
tional areas printed with a wax printer that merges all processes (extraction, enrichment, purification, elution, amplification, and visual detection) requested for nucleic acid testing into an inexpensive paper material. The full testing operation could be performed via easy folding of a paper-founded apparatus in diverse manners in numerous stages without a pump or power supply, which beats the restriction of PCR and averts numerous operations. Paper analytical gadgets allow multiplexed, precise checks that challenge PCR laboratory checks and furnish high-quality, rapid precision diagnostics for pathogens. As an illustration, researchers have established the multiplexed diagnosis of malaria from whole blood utilizing a paper-founded gadget in rural Uganda [14]. The inspection can sensitively examine multiplexed nucleic acid sequences of pathogens after only $50 \mathrm{~min}$, which furnished a higher-quality and quicker precision diagnosis for malaria than PCR [10].

On the other hand, paper analytical gadgets are facile to stack, store, and transport as they are thin, lightweight, and of various thicknesses. Visual analysis is performed easily thanks to the strong contrast with a colored substrate. Paper-based apparatuses could as well be incinerated following usage, decreasing the hazard of more pollution [10].

Even if wastewater stays a complex matrix, paper-founded gadgets have proved the possibility to uncover pathogens in wastewater. Yang et al. [11] suggested a rapid "sample-to-answer" analysis procedure that could furnish quantitative control of nucleic acids and genetic information via the analysis of sewage, which was affirmed using a robust electrophoresis and agarose gel image assay, illustrating encouraging reliability for wastewater analysis. More paper-founded gadgets have as well been made for infectious diseases and pathogens discovery (Table 1) [10].

\section{Main Environmental Engineering's Challenges towards Stopping Viruses Pandemics}

Engineers and scientists specialized in the environment have efficiently participated in saving the public from viral illnesses, and push along to do so now [15]-[20]. They promoted potable water and domestic wastewater treatment techniques, realized inventions that notify regarding regulations and policies, and performed crucial studies on the occurrence, continuity, and diffusion of viruses in nature [21] [22] [23] [24] [25]. A large collection of outstanding investigation in this domain has been dedicated mostly to non-enveloped human enteric viruses like human noroviruses and enteroviruses [26] [27] [28] [29] [30]. As mentioned above, not long ago, numerous high-profile eruptions like Ebola virus, measles, Zika virus, avian influenzas, SARS, MERS, and the continuing COVID-19 pandemic have been provoked by enveloped viruses. In addition to the ribonucleic acid (RNA) or deoxyribonucleic acid (DNA) genomes and protective protein capsids that are common to all viruses, enveloped virus structures are also wrapped in bi-lipid membranes. 
Table 1. Instances of paper-founded gadgets for infectious diseases and pathogens determination [10].

\begin{tabular}{|c|c|c|}
\hline Infectious diseases/pathogens & Features of paper-founded gadgets & Detection procedure \\
\hline Malaria & Paper gadget combined vertical flow sample-processing steps & Visual UV/lateral flow device \\
\hline Rotavirus A & $\begin{array}{l}\text { Integrated nucleic acid test on a single paper device, including } \\
\text { extraction, amplification, and on-site detection }\end{array}$ & Naked eye \\
\hline Zika virus & Wax-printed paper devices utilizing isothermal amplification & Smartphone \\
\hline Human papillomavirus & $\begin{array}{l}\text { Paper device in a foldable system allowing for fully integrated } \\
\text { operation from sample to result }\end{array}$ & Lateral flow device \\
\hline Human immunodeficiency virus (HIV) & Paper devices fabricated with cellulose paper and flexible plastic plate & Electrochemistry \\
\hline Neisseria meningitides & Versatile paper devices integrated with isothermal amplification & Visual fluorescence \\
\hline Listeria monocytogenes & Loop-mediated isothermal amplification (LAMP)-based paper devices & Visual fluorescence \\
\hline Cochlodinium polykrikoides & Paper devices based on LAMP & Visual fluorescence \\
\hline Staphylococcus aureus & Self-priming paper devices & Visual fluorescence \\
\hline Vibrio parahemolyticus & Self-priming paper devices & Visual fluorescence \\
\hline Mycobacterium smegmatis & $\begin{array}{l}\text { Paper devices combined thermal lysis and isothermal amplification } \\
\text { into a single step }\end{array}$ & Visual fluorescence \\
\hline Bacillus subtilis & A wax-printed cellulose paper device & Colorimetry \\
\hline Salmonella & $\begin{array}{l}\text { Paper devices integrated with purification, amplification, and on-site } \\
\text { detection }\end{array}$ & Colorimetry \\
\hline \multirow{5}{*}{ Escherichia coli } & Foldable paper devices with the ability of long-term reagents storage & Colorimetry \\
\hline & Paper devices based on isothermal amplification and on-chip detection & Visual fluorescence \\
\hline & $\begin{array}{l}\text { Paper machine integrated sample preparation and isothermal } \\
\text { amplification with end point detection }\end{array}$ & Visual UV/camera \\
\hline & $\begin{array}{l}\text { Paper devices integrated extraction, purification, amplification and } \\
\text { detection }\end{array}$ & Smartphone/naked eye \\
\hline & Paper devices combined thermal lysis and isothermal amplification & Visual fluorescence \\
\hline Bovine infectious reproductive diseases & Multiplexed and point-of-care paper-analytical device & Visual UV/smartphone \\
\hline $\begin{array}{l}\text { Highly pathogenic strain of porcine } \\
\text { reproductive and respiratory syndrome } \\
\text { virus (HP-PRRSV) }\end{array}$ & Paper devices fabricated with filter paper and plastic chip & Colorimetry \\
\hline
\end{tabular}

As aforesaid, the main manner of transmission for several enveloped viruses remains through approaching contact with infected persons [15]. Numerous enveloped viruses, even so, are liberated to nature by the host and remain on surfaces (i.e., fomites), in the air, or in water, long enough to come into contact with another host for additional onward transmission (that is to say, indirect transmission). This comprises viruses in charge of influenza and measles. The first transmission ways for SARS-CoV-2 (the virus that provokes COVID-19) are approved to be person-to-person touch and through subjection to big droplets formed from sneezing, coughing or talking; however, indirect transmission ways may as well contribute [31]. Such a likely contribution of nature in the diffusion of COVID-19 picks out the plenty of technological deficiencies that should be confronted to efficiently dominate eruptions and pandemics as fresh enveloped viruses come out.

Virus particles in the air and on fomites are open to a collection of ecological circumstances that dictate their continuity [15]. Relative humidity, fomite ma- 
terial, and air temperature could considerably affect enveloped virus demobilization rates [32] [33] [34] [35]. Indeed, the environment in which the virus is suspended could considerably affect duration [36]. As an illustration, chlorine-founded solutions [37] [38] [39] [40] [41] and hydrogen peroxide gas are efficient at demobilizing the enveloped virus surrogate Phi6 on fomites [42] [43]; however, the occurrence of blood requests much higher hydrogen peroxide gas injections [43]. Next mechanistic investigations have to check how particular constituents in the matrix, temperature, humidity, and solar radiation each affect demobilization. In addition, a survey measuring the transfer of enveloped viruses among fomites and skin, and defining efficient hand washing and surface sanitizing manners is required to inform agent-based risk assessment models.

As shown previously, viruses possess a direct link to wastewater and potable water treatment when they are expelled in feces or urine (Table 2) [44]; however, there are restricted details on the level of enveloped viruses in feces and urine. The human coronavirus in charge of the 2003 SARS explosion was fit to replicate in the human gastrointestinal (GI) tract and infective particles were found in stool samples [45]. As mentioned above, in fact, aerosolized fecal particles are supposed to possess the main contribution in diffusing the virus at a Hong Kong apartment complex [9]. In a similar fashion, SARS-CoV-2 genomic RNA has been found in feces [12] [46]. Even if infective SARS-CoV-2 has not until now been asserted in stool samples, the SARS-CoV-2 RNA shedding pattern proposes viruses are replicating in the GI tract [46]. Other human enveloped viruses, like cytomegalovirus (CMV), are evacuated in the urine. Previous studies on enveloped viruses in wastewater, comprising coronaviruses, propose that such viruses are demobilized at faster rates than most non-enveloped viruses [47] [48] [49] [50] [51], that they partition to wastewater solids to a greater extent than non-enveloped viruses [51], and that wastewater temperature is positively related to their demobilization rates [49] [51]. In water treatment techniques, they are usually more vulnerable to oxidant disinfectants than non-enveloped viruses [52] [53] [54]. The existence of an envelope does not seem to affect virus vulnerability to ultraviolet C (UVC) light [51], possibly due to UVC targets virus genomes and lipid membranes do not shield the genomes from UVC radiation [15].

Table 2. Mean or median viral loads in the feces and urine of infected individuals for three enveloped viruses and two non-enveloped viruses ${ }^{\mathrm{a}}[15]$.

\begin{tabular}{ccccc}
\hline Virus & Enveloped or not & Urine $(\mathrm{gc} / \mathrm{mL})$ & Feces $(\mathrm{gc} / \mathrm{g})$ & Feces $(\mathrm{gc} / \mathrm{swab})$ \\
\hline SARS $^{b}$ & Yes & $10^{1.3}$ & $10^{6.1}$ & NA \\
${\text { Cytomegalovirus }(\mathrm{CMV})^{C}}^{C}$ & Yes & $10^{4.5}$ & $\mathrm{NA}$ & $\mathrm{NA}$ \\
SARS-CoV-2 $^{d}$ & Yes & $\mathrm{ND}$ & $\mathrm{NA}$ & $10^{5}$ \\
Human norovirus GII $^{e}$ & No & NA & $10^{8.5}$ & NA \\
JC polyomavirus $^{f}$ & No & $10^{4.6}$ & $\mathrm{NA}$ & NA \\
\hline
\end{tabular}

a“gc" is gene copy. NA = not analyzed in study, ND = analyzed, but not detected in study. ${ }^{b}$ Samples from approximately 100 patients with lab-confirmed illness, mean. 'Samples from 36 children with lab-confirmed illness, median. ${ }^{d}$ Rectal swab samples from 9 patients with lab-confirmed illness during first week of illness, mean. ${ }^{e}$ Samples from 627 patients with gastroenteritis symptoms, median. ${ }^{f}$ Samples from 71 health blood donors that tested positive or JC polyomavirus, median. 


\section{Water Treatment Plants Facing SARS-CoV-2 Virus}

What does this imply for the SARS-CoV-2 virus and the potential of the water treatment plants to guarantee protected water? The present potable water treatment plants [55]-[62], involving those utilized to get potable water from wastewater [63]-[68], were planed employing microbial risk assessments and process efficiency data with non-enveloped enteric viruses. Founded on the realities that 1) the closely related 2003 SARS was expelled in feces at lower degrees than enteric human noroviruses (Table 2), 2) model coronaviruses are demobilized at quicker rates in wastewater and other waters than non-enveloped viruses, 3) the enveloped viruses tested until now are more vulnerable to oxidant disinfectants than non-enveloped viruses, and 4) the large single-stranded RNA (ssRNA) genome $(\sim 29.8 \mathrm{~kb})$ of SARS-CoV-2 possibly renders it more vulnerable to UVC inactivation than enteric ssRNA viruses, the multi-barrier wastewater and potable water treatment systems are probably efficient in keeping safe against SARS-CoV-2. Even so, there may still be water-related subjections that require to be taken into account if infectious SARS-CoV-2 viruses are existing in urine or feces. Such subjections could happen in communities that experience combined sewage overflows, that do not have sewage infrastructure, or that use wastewater for irrigation [69]-[75], as well as buildings that have faulty plumbing systems and occupational exposures to wastewater and excrement [15].

Even with the study summarized earlier, enveloped viruses are very various, with a collection of genome types, structures, replication cycles, and pathogenicities. As an illustration, of the 158 specified human RNA viruses' species as of 2018, 122 species from 11 virus families were enveloped and 36 species from 6 families were non-enveloped [76]. Thus, enveloped viruses probably manifest a different assortment of ecological comportment, endurance, and fate [77]. The restricted investigations on enveloped-virus fate, transport, and demobilization have been dedicated to only a small portion of human viruses or their proxies comprising animal coronaviruses and bacteriophage phi6. Even if investigations employing animal coronaviruses have been useful for the present COVID-19 eruption [34] [51] [78], it is important to examine an extended collection of enveloped viruses that better represent human enveloped virus diversity [15].

Next studies on enveloped viruses have to search for accurately qualify and even standardize the circumstances under which measurements are performed [15]. Media composition, the purity of virus stock, and if feasible, virus levels in both gene copies and infective units, must be defined. While examining oxidants, the demand for the solution and variation in oxidant dosage during the test has to be furnished [79] [80] [81]. While trying radiation (UVC [82] and/or sunlight [83]), mitigation via the experimental solution must be well-featured incorporated into reported injections [84] [85] [86] [87] [88]. Scientists have to involve a well-tested surrogate virus in their trials in addition to the enveloped virus of attention to make easier cross-study rapprochements. Wigginton and Boehm 2020 [15] suggested employing the non-enveloped bacteriophage MS2 
for such objective since it is one of the most examined viruses in ecosystems [89].

Consequently, there are rising research perspectives in this domain, which could demystify the actual COVID-19 eruption and following fresh viral eruptions. For instance, prognostic models founded on the fundamental pathways managing the endurance of enveloped viruses, and other properties, could diminish the necessity to investigate every virus below every circumstance [47]. One more encouraging field of study implicates employing sewage to control virus diffusion in communities and discover eruptions before clinical cases are noticed. Lately implemented to pathogenic microbes [90] and non-enveloped viruses [15], this will require a better comprehension of which enveloped viruses are expelled in urine and feces and at what degrees [15].

\section{Conclusions}

From this work, the main conclusions emerge:

1) The menace of COVID-19 eruption is not restricted to any one country or region. The response, control, and prevention of new infectious diseases need powerful and potential global cooperative work and data sharing. More investigation is urgent to plug the knowledge vacuums on COVID-19. In addition to proficiency in the domains of medicine, public health, and computer science, the participation of environmental researchers in a collaborative investigation is desperately justified for fighting the infectious disease danger at a worldwide level [3].

2) The paper-founded gadget possesses the capacity to be employed as a small, portable setup to reveal SARS-CoV-2 in wastewater on-site and to follow virus carriers in the community. This procedure can give near real-time and continuous data and work as a premature warning sensing device to assist local governments and agencies take efficient actions to sequester potential virus carriers and avoid the diffusion of epidemics. In the situation of asymptomatic infections in the community or people are not certain if they are infected or not, fast and real-time community sewage detection via paper analytical gadgets could decide if there are SARS-CoV-2 carriers in the zone in an appropriate fashion to allow quick screening, quarantine, and prevention. The potentially infected patient will also benefit from paper analytical device tracing SARS-CoV-2 sources with WBE, providing information for the correct and timely treatment of COVID-19. [10].

3) SARS-CoV-2 will surely not be the ultimate fresh virus to jut and badly terrorize worldwide public health and life [15]. Scientists and funding agencies have a trend to concentrate largely on a particular virus throughout its eruption; however, then advance on to different themes when the eruption calms. Considering the historical contributions from environmental engineering, and the huge dares that emerge [10], environmental science and engineering specialists have to adopt a larger, long-term, and more quantitative strategy to compre- 
hending viruses that are diffusing through nature. Identical to the manner by which chemical contaminants are handled in the environment, the particular properties that control transport and demobilization of enveloped viruses in solutions, on surfaces, and in the air must be understood. Besides, the fashion by which ecological parameters form likely virus transmission mechanisms should be comprehended. Thereby, despite the identity of the enveloped virus that provokes the following main eruption, more sophisticated detailing of its endurance and guidance on how to reduce its diffusion may be given.

\section{Acknowledgements}

This research has been funded by the Research Deanship of University of Ha'il, Saudi Arabia, through the Project RG-191190.

\section{Conflicts of Interest}

The authors declare no conflicts of interest regarding the publication of this paper.

\section{References}

[1] Boehm, A. and Wigginton, K. (2020) Overview of Research on the Fate and Behavior of Enveloped Viruses in the Environment, Virtual Issue.

https://pubs.acs.org/page/esthag/vi/coronavirus-survival-behavior?utm_source=pub

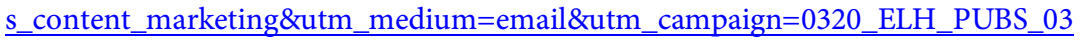

20_ELH_ES_Coronavirus_VI_Email\&ref=pubs_content_marketing

[2] Ghernaout, D. (2019) Virus Removal by Electrocoagulation and Electrooxidation: New Findings and Future Trends. Journal of Environmental Science and Allied Research, 2019, 85-90.

[3] Qu, G., Li, X., Hu, L. and Jiang, G. (2020) An Imperative Need for Research on the Role of Environmental Factors in Transmission of Novel Coronavirus (COVID-19). Environmental Science \& Technology, 54, 3730-3732. https://doi.org/10.1021/acs.est.0c01102

[4] Coronavirus Disease (COVID-19) Situation Dashboard. https://covid19.who.int/

[5] Wang, C., Horby, P.W., Hayden, F.G. and Gao, G.F. (2020) A Novel Coronavirus Outbreak of Global Health Concern. The Lancet, 395, 470-473.

https://doi.org/10.1016/S0140-6736(20)30185-9

[6] Weber, D.J., Rutala, W.A., Fischer, W.A., Kanamori, H. and Sickbert-Bennett, E.E. (2016) Emerging Infectious Diseases: Focus on Infection Control Issues for Novel Coronaviruses (Severe Acute Respiratory Syndrome-CoV and Middle East Respiratory Syndrome-CoV), Hemorrhagic Fever Viruses (Lassa and Ebola), and Highly Pathogenic Avian Influenza Viruses, $\mathrm{A}(\mathrm{H} 5 \mathrm{~N} 1)$ and $\mathrm{A}(\mathrm{H} 7 \mathrm{~N} 9)$. American Journal of Infection Control, 44, E91-E100. https://doi.org/10.1016/j.ajic.2015.11.018

[7] Casanova, L., Rutala, W.A., Weber, D.J. and Sobsey, M.D. (2009) Survival of Surrogate Coronaviruses in Water. Water Research, 43, 1893-1898. https://doi.org/10.1016/j.watres.2009.02.002

[8] Peiris, J.S., Chu, C.M., Cheng, V.C., Chan, K.S., Hung, I.F., Poon, L.L., Law, K.I., Tang, B.S., Hon, T.Y., Chan, C.S., Chan, K.H., Ng, J.S., Zheng, B.J., Ng, W.L., Lai, R.W., Guan, Y. and Yuen, K.Y. (2003) Clinical Progression and Viral Load in a 
Community Outbreak of Coronavirus-Associated SARS Pneumonia: A Prospective Study. The Lancet, 361, 1767-1772. https://doi.org/10.1016/S0140-6736(03)13412-5

[9] Yu, I.T., Li, Y., Wong, T.W., Tam, W., Chan, A.T., Lee, J.H., Leung, D.Y. and Ho, T. (2004) Evidence of Airborne Transmission of the Severe Acute Respiratory Syndrome Virus. The New England Journal of Medicine, 350, 1731-1739. https://doi.org/10.1056/NEJMoa032867

[10] Mao, K., Zhang, H. and Yang, Z. (2020) Can a Paper-Based Device Trace COVID-19 Sources with Wastewater-Based Epidemiology? Environmental Science \& Technology. https://doi.org/10.1021/acs.est.0c01174

[11] Yang, Z., Kasprzyk-Hordern, B., Frost, C.G., Estrela, P. and Thomas, K.V. (2015) Community Sewage Sensors for Monitoring Public Health. Environmental Science \& Technology, 49, 5845-5846. https://doi.org/10.1021/acs.est.5b01434

[12] Holshue, M.L., DeBolt, C., Lindquist, S., Lofy, K.H., Wiesman, J., Bruce, H., Spitters, C., Ericson, K., Wilkerson, S., Tural, A., Diaz, G., Cohn, A., Fox, L., Patel, A., Gerber, S.I., Kim, L., Tong, S., Lu, X., Lindstrom, S., Pallansch, M.A., Weldon, W.C., Biggs, H.M., Uyeki, T.M. and Pillai, S.K. (2020) First Case of 2019 Novel Coronavirus in the United States. The New England Journal of Medicine, 382, 929-936. https://doi.org/10.1056/NEJMoa2001191

[13] Magro, L., Escadafal, C., Garneret, P., Jacquelin, B., Kwasiborski, A., Manuguerra, J.C., Monti, F., Sakuntabhai, A., Vanhomwegen, J., Lafaye, P. and Tabeling, P. (2017) Paper Microfluidics for Nucleic Acid Amplification Testing (NAAT) of Infectious Diseases. Lab on a Chip, 17, 2347-2371. https://doi.org/10.1039/C7LC00013H

[14] Reboud, J., Xu, G., Garrett, A., Adriko, M., Yang, Z., Tukahebwa, E.M., Rowell, C. and Cooper, J.M. (2019) Paper-Based Microfluidics for DNA Diagnostics of Malaria in Low Resource Underserved Rural Communities. Proceedings of the National Academy of Sciences of the United States of America, 116, 4834-4842.

https://doi.org/10.1073/pnas.1812296116

[15] Wigginton, K.R. and Boehm, A.B. (2020) Environmental Engineers and Scientists Have Important Roles to Play in Stemming Outbreaks and Pandemics Caused by Enveloped Viruses. Environmental Science \& Technology, 54, 3736-3739. https://doi.org/10.1021/acs.est.0c01476

[16] Ghernaout, D. (2017) Environmental Principles in the Holy Koran and the Sayings of the Prophet Muhammad. American Journal of Environmental Protection, 6, 75-79. https://doi.org/10.11648/j.ajep.20170603.13

[17] Ghernaout, D., Ghernaout, B. and Naceur, M.W. (2011) Embodying the Chemical Water Treatment in the Green Chemistry-A Review. Desalination, 271, 1-10. https://doi.org/10.1016/j.desal.2011.01.032

[18] Ghernaout, D. and Ghernaout, B. (2010) From Chemical Disinfection to Electrodisinfection: The Obligatory Itinerary? Desalination and Water Treatment, 16, 156-175. https://doi.org/10.5004/dwt.2010.1085

[19] Boucherit, A., Moulay, S., Ghernaout, D., Al-Ghonamy, A.I., Ghernaout, B., Naceur, M.W., Ait Messaoudene, N., Aichouni, M., Mahjoubi, A.A. and Elboughdiri, N.A. (2015) New Trends in Disinfection By-Products Formation upon Water Treatment. Journal of Research \& Developments in Chemistry, 2015, Article ID: 628833. https://doi.org/10.5171/2015.628833

[20] Ghernaout, D. (2017) Microorganisms' Electrochemical Disinfection Phenomena. EC Microbiology, 9, 160-169.

[21] Ghernaout, D. (2018) Disinfection and DBPs Removal in Drinking Water Treat- 
ment: A Perspective for a Green Technology. International Journal of Advanced and Applied Sciences, 5, 108-117. https://doi.org/10.21833/ijaas.2018.02.018

[22] Ghernaout, D., Touahmia, M. and Aichouni, M. (2019) Disinfecting Water: Electrocoagulation as an Efficient Process. Applied Engineering, 3, 1-12.

[23] Ghernaout, D., Aichouni, M. and Touahmia, M. (2019) Mechanistic Insight into Disinfection by Electrocoagulation: A Review. Desalination and Water Treatment, 141, 68-81. https://doi.org/10.5004/dwt.2019.23457

[24] Ghernaout, D., Alghamdi, A. and Ghernaout, B. (2019) Microorganisms' Killing: Chemical Disinfection vs. Electrodisinfection. Applied Engineering, 3, 13-19.

[25] Ghernaout, D. (2019) Greening Electrocoagulation Process for Disinfecting Water. Applied Engineering, 3, 27-31.

[26] Ghernaout, D. (2019) Electrocoagulation and Electrooxidation for Disinfecting Water: New Breakthroughs and Implied Mechanisms. Applied Engineering, 3, 125-133.

[27] Ghernaout, D. and Elboughdiri, N. (2019) Electrocoagulation Process Intensification for Disinfecting Water: A Review. Applied Engineering, 3, 140-147.

[28] Ghernaout, D. and Elboughdiri, N. (2019) Iron Electrocoagulation Process for Disinfecting Water: A Review. Applied Engineering, 3, 154-158.

[29] Ghernaout, D. (2019) Disinfection via Electrocoagulation Process: Implied Mechanisms and Future Tendencies. EC Microbiology, 15, 79-90.

[30] Ghernaout, D. and Elboughdiri, N. (2019) Mechanistic Insight into Disinfection Using Ferrate(VI). Open Access Library Journal, 6, e5946.

[31] Cai, J., Sun, W., Huang, J., Gamber, M., Wu, J. and He, G. (2020) Indirect Virus Transmission in Cluster of COVID-19 Cases Wenzhou, China 2020. Emerging Infectious Diseases, 26. https://doi.org/10.3201/eid2606.200412

[32] Kim, Y., Krishna, V.D., Torremorell, M., Goyal, S.M. and Cheeran, M.C.-J. (2018) Stability of Porcine Epidemic Diarrhea Virus on Fomite Materials at Different Temperatures. Veterinary Science, 5, 21. https://doi.org/10.3390/vetsci5010021

[33] Lin, K. and Marr, L.C. (2020) Humidity-Dependent Decay of Viruses, But Not Bacteria, in Aerosols and Droplets Follows Disinfection Kinetics. Environmental Science \& Technology, 54, 1024-1032. https://doi.org/10.1021/acs.est.9b04959

[34] Casanova, L.M., Jeon, S., Rutala, W.A., Weber, D.J. and Sobsey, M.D. (2010) Effects of Air Temperature and Relative Humidity on Coronavirus Survival on Surfaces. Applied and Environmental Microbiology, 76, 2712-2717. https://doi.org/10.1128/AEM.02291-09

[35] Casanova, L., Rutala, W.A., Weber, D.J. and Sobsey, M.D. (2010) Coronavirus Survival on Healthcare Personal Protective Equipment. Infection Control \& Hospital Epidemiology, 31, 560-561. https://doi.org/10.1086/652452

[36] Walker, C.M. and Ko, G. (2007) Effect of Ultraviolet Germicidal Irradiation on Viral Aerosols. Environmental Science \& Technology, 41, 5460-5465. https://doi.org/10.1021/es070056u

[37] Ghernaout, D., Naceur, M.W. and Aouabed, A. (2011) On the Dependence of Chlorine By-Products Generated Species Formation of the Electrode Material and Applied Charge during Electrochemical Water Treatment. Desalination, 270, 9-22. https://doi.org/10.1016/j.desal.2011.01.010

[38] Ghernaout, D., Alghamdi, A., Aichouni, M. and Touahmia, M. (2018) The Lethal Water Tri-Therapy: Chlorine, Alum, and Polyelectrolyte. World Journal of Applied Chemistry, 3, 65-71. https://doi.org/10.11648/j.wjac.20180302.14 
[39] Ghernaout, D. and Elboughdiri, N. (2020) Is Not It Time to Stop Using Chlorine for Treating Water? Open Access Library Journal, 7, e6007.

[40] Ghernaout, D., Moulay, S., Ait Messaoudene, N., Aichouni, M., Naceur, M.W. and Boucherit, A. (2014) Coagulation and Chlorination of NOM and Algae in Water Treatment: A Review. International Journal of Environmental Monitoring and Analysis, 2, 23-34. https://doi.org/10.11648/j.ijema.s.2014020601.14

[41] Ghernaout, D. (2017) Water Treatment Chlorination: An Updated Mechanistic Insight Review. Chemistry Research Journal, 2, 125-138.

[42] Gallandat, K., Wolfe, M.K. and Lantagne, D. (2017) Surface Cleaning and Disinfection: Efficacy Assessment of Four Chlorine Types Using Escherichia coli and the Ebola Surrogate Phi6. Environmental Science \& Technology, 51, 4624-4631. https://doi.org/10.1021/acs.est.6b06014

[43] Wood, J.P., Richter, W., Sunderman, M., Calfee, M.W., Serre, S. and Mickelsen, L. (2020) Evaluating the Environmental Persistence and Inactivation of MS2 Bacteriophage and the Presumed Ebola Virus Surrogate Phi6 Using Low Concentration Hydrogen Peroxide Vapor. Environmental Science \& Technology, 54, 3581-3590. https://doi.org/10.1021/acs.est.9b06034

[44] Wigginton, K.R., Ye, Y. and Ellenberg, R.M. (2015) Emerging Investigators Series: The Source and Fate of Pandemic Viruses in the Urban Water Cycle. Environmental Science: Water Research \& Technology, 1, 735-746. https://doi.org/10.1039/C5EW00125K

[45] Leung, W.K., To, K., Chan, P.K.S., Chan, H.L.Y., Wu, A.K.L., Lee, N., Yuen, K.Y. and Sung, J.J.Y. (2003) Enteric Involvement of Severe Acute Respiratory Syndrome-Associated Coronavirus Infection. Gastroenterology, 125, 1011-1017. https://doi.org/10.1016/j.gastro.2003.08.001

[46] Woelfel, R., Corman, V.M., Guggemos, W., Seilmaier, M., Zange, S., Mueller, M.A., Niemeyer, D., Vollmar, P., Rothe, C., Hoelscher, M., Bleicker, T., Bruenink, S., Schneider, J., Ehmann, R., Zwirglmaier, K., Drosten, C. and Wendtner, C. (2020) Clinical Presentation and Virological Assessment of Hospitalized Cases of Coronavirus Disease 2019 in a Travel-Associated Transmission Cluster. Infectious Diseases (except HIVIAIDS). https://doi.org/10.1101/2020.03.05.20030502

[47] Brainard, J., Pond, K. and Hunter, P.R. (2017) Censored Regression Modeling to Predict Virus Inactivation in Wastewaters. Environmental Science \& Technology, 51, 1795-1801. https://doi.org/10.1021/acs.est.6b05190

[48] Bibby, K., Fischer, R.J., Casson, L.W., Stachler, E., Haas, C.N. and Munster, V.J. (2015) Persistence of Ebola Virus in Sterilized Wastewater. Environmental Science \& Technology Letters, 2, 245-249. https://doi.org/10.1021/acs.estlett.5b00193

[49] Gundy, P.M., Gerba, C.P. and Pepper, I.L. (2009) Survival of Coronaviruses in Water and Wastewater. Food and Environmental Virology, 1, 10. https://doi.org/10.1007/s12560-008-9001-6

[50] Casanova, L.M. and Weaver, S.R. (2015) Inactivation of an Enveloped Surrogate Virus in Human Sewage. Environmental Science \& Technology Letters, 2, 76-78. https://doi.org/10.1021/acs.estlett.5b00029

[51] Ye, Y., Ellenberg, R.M., Graham, K.E. and Wigginton, K.R. (2016) Survivability, Partitioning, and Recovery of Enveloped Viruses in Untreated Municipal Wastewater. Environmental Science \& Technology, 50, 5077-5085. https://doi.org/10.1021/acs.est.6b00876

[52] Rice, E.W., Adcock, N.J., Sivaganesan, M., Brown, J.D., Stallknecht, D.E. and 
Swayne, D.E. (2007) Chlorine Inactivation of Highly Pathogenic Avian Influenza Virus (H5N1). Emerging Infectious Diseases, 13, 1568-1570. https://doi.org/10.3201/eid1310.070323

[53] Qiao, Z., Ye, Y., Chang, P.H., Thirunarayanan, D. and Wigginton, K.R. (2018) Nucleic Acid Photolysis by $\mathrm{UV}_{254}$ and the Impact of Virus Encapsidation. Environmental Science \& Technology, 52, 10408-10415. https://doi.org/10.1021/acs.est.8b02308

[54] Ye, Y., Chang, P.H., Hartert, J. and Wigginton, K.R. (2018) Reactivity of Enveloped Virus Genome, Proteins, and Lipids with Free Chlorine and $\mathrm{UV}_{254}$. Environmental Science \& Technology, 52, 7698-7708. https://doi.org/10.1021/acs.est.8b00824

[55] Ghernaout, D. and Elboughdiri, N. (2019) Water Disinfection: Ferrate(VI) as the Greenest Chemical: A Review. Applied Engineering, 3, 171-180.

[56] Ghernaout, D. and Elboughdiri, N. (2020) Strategies for Reducing Disinfection By-Products Formation during Electrocoagulation. Open Access Library Journal, 7, e6076. https://doi.org/10.4236/oalib.1106076

[57] Ghernaout, D. and Elboughdiri, N. (2020) Electrocoagulation Process in the Context of Disinfection Mechanism. Open Access Library Journal, 7, e6083.

[58] Ghernaout, D. and Elboughdiri, N. (2020) Disinfection By-Products: Presence and Elimination in Drinking Water. Open Access Library Journal, 7, e6140.

[59] Ghernaout, D. and Elboughdiri, N. (2020) Controlling Disinfection By-Products Formation in Rainwater: Technologies and Trends. Open Access Library Journal, 7, e6162. https://doi.org/10.4236/oalib.1106162

[60] Ghernaout, D., Elboughdiri, N., Ghareba, S. and Salih, A. (2020) Electrochemical Advanced Oxidation Processes (EAOPs) for Disinfecting Water: Fresh Perspectives. Open Access Library Journal, 7, e6257. https://doi.org/10.4236/oalib.1106257

[61] Ghernaout, D. and Elboughdiri, N. (2020) Towards Enhancing Ozone Diffusion for Water Disinfection: Short Notes. Open Access Library Journal, 7, e6253.

[62] Ghernaout, D., Elboughdiri, N., Ghareba, S. and Salih, A. (2020) Disinfecting Water with the Carbon Fiber-Based Flow-Through Electrode System (FES): Towards Axial Dispersion and Velocity Profile. Open Access Library Journal, 7, e6238. https://doi.org/10.4236/oalib.1106238

[63] Ghernaout, D. (2017) Water Reuse (WR): The Ultimate and Vital Solution for Water Supply Issues. International Journal of Sustainable Development Research, 3, 36-46. https://doi.org/10.11648/j.ijsdr.20170304.12

[64] Ghernaout, D., Alshammari, Y., Alghamdi, A., Aichouni, M., Touahmia, M. and Ait Messaoudene, N. (2018) Water Reuse: Extenuating Membrane Fouling in Membrane Processes. International Journal of Environmental Chemistry, 2, 1-12. https://doi.org/10.11648/j.ajche.20180602.12

[65] Ghernaout, D., Elboughdiri, N. and Al Arni, S. (2019) Water Reuse (WR): Dares, Restrictions, and Trends. Applied Engineering, 3, 159-170.

[66] Ghernaout, D., Elboughdiri, N. and Ghareba, S. (2019) Drinking Water Reuse: One-Step Closer to Overpassing the "Yuck Factor". Open Access Library Journal, 6, e5895. https://doi.org/10.4236/oalib.1105895

[67] Ghernaout, D. and Elboughdiri, N. (2019) Water Reuse: Emerging Contaminants Elimination-Progress and Trends. Open Access Library Journal, 6, e5981.

[68] Ghernaout, D. and Elboughdiri, N. (2020) On the Treatment Trains for Municipal Wastewater Reuse for Irrigation. Open Access Library Journal, 7, e6088.

[69] Ghernaout, D. (2013) The Best Available Technology of Water/Wastewater Treat- 
ment and Seawater Desalination: Simulation of the Open Sky Seawater Distillation. Green and Sustainable Chemistry, 3, 68-88. https://doi.org/10.4236/gsc.2013.32012

[70] Ghernaout, D. (2018) Increasing Trends towards Drinking Water Reclamation from Treated Wastewater. World Journal of Applied Chemistry, 3, 1-9. https://doi.org/10.11648/j.wjac.20180301.11

[71] Ghernaout, D., Alshammari, Y. and Alghamdi, A. (2018) Improving Energetically Operational Procedures in Wastewater Treatment Plants. International Journal of Advanced and Applied Sciences, 5, 64-72. https://doi.org/10.21833/ijaas.2018.09.010

[72] Al Arni, S., Amous, J. and Ghernaout, D. (2019) On the Perspective of Applying of a New Method for Wastewater Treatment Technology: Modification of the Third Traditional Stage with Two Units, One by Cultivating Microalgae and Another by Solar Vaporization. International Journal of Environmental Sciences \& Natural Resources, 16, Article ID: 555934. https://doi.org/10.19080/IJESNR.2019.16.555934

[73] Ghernaout, D. (2019) Reviviscence of Biological Wastewater Treatment: A Review. Applied Engineering, 3, 46-55.

[74] Ghernaout, D. and Elboughdiri, N. (2019) Upgrading Wastewater Treatment Plant to Obtain Drinking Water. Open Access Library Journal, 6, e5959. https://doi.org/10.4236/oalib.1105959

[75] Ghernaout, D. and Elboughdiri, N. (2020) Electrochemical Technology for Wastewater Treatment: Dares and Trends. Open Access Library Journal, 7, e6020.

[76] Woolhouse, M.E.J. and Adair, K. (2013) The Diversity of Human RNA Viruses. Future Virology, 8, 159-171. https://doi.org/10.2217/fvl.12.129

[77] Aquino de Carvalho, N., Stachler, E.N., Cimabue, N. and Bibby, K. (2017) Evaluation of Phi6 Persistence and Suitability as an Enveloped Virus Surrogate. Environmental Science \& Technology, 51, 8692-8700.

https://doi.org/10.1021/acs.est.7b01296

[78] Hulkower, R.L., Casanova, L.M., Rutala, W.A., Weber, D.J. and Sobsey, M.D. (2011) Inactivation of Surrogate Coronaviruses on Hard Surfaces by Healthcare Germicides. American Journal of Infection Control, 39, 401-407. https://doi.org/10.1016/j.ajic.2010.08.011

[79] Ghernaout, D. and Elboughdiri, N. (2020) Advanced Oxidation Processes for Wastewater Treatment: Facts and Future Trends. Open Access Library Journal, 7, e6139.

[80] Ghernaout, D. and Elboughdiri, N. (2020) Domestic Wastewater Treatment: Difficulties and Reasons, and Prospective Solutions-China as an Example. Open Access Library Journal, 7, e6141.

[81] Ghernaout, D. (2020) Advanced Oxidation Phenomena in Electrocoagulation Process: A Myth or a Reality? Desalination and Water Treatment, 51, 7536-7554. https://doi.org/10.1080/19443994.2013.792520

[82] Ghernaout, D. and Elboughdiri, N. (2020) UV-C/ $/ \mathrm{H}_{2} \mathrm{O}_{2}$ and Sunlight $/ \mathrm{H}_{2} \mathrm{O}_{2}$ in the Core of the Best Available Technologies for Dealing with Present Dares in Domestic Wastewater Reuse. Open Access Library Journal, 7, e6161. https://doi.org/10.4236/oalib.1106161

[83] Ghernaout, D., Alghamdi, A., Touahmia, M., Aichouni, M. and Ait Messaoudene, N. (2018) Nanotechnology Phenomena in the Light of the Solar Energy. Journal of Energy, Environmental \& Chemical Engineering, 3, 1-8. https://doi.org/10.11648/j.jeece.20180301.11

[84] Ghernaout, D., Badis, A., Ghernaout, B. and Kellil, A. (2008) Application of Elec- 
trocoagulation in Escherichia coli Culture and Two Surface Waters. Desalination, 219, 118-125. https://doi.org/10.1016/j.desal.2007.05.010

[85] Belhout, D., Ghernaout, D., Djezzar-Douakh, S. and Kellil, A. (2010) Electrocoagulation of a Raw Water of Ghrib Dam (Algeria) in Batch Using Iron Electrodes. Desalination and Water Treatment, 16, 1-9. https://doi.org/10.5004/dwt.2010.1081

[86] Ghernaout, D. (2018) Electrocoagulation Process: Achievements and Green Perspectives. Colloid and Surface Science, 3, 1-5.

https://doi.org/10.11648/j.css.20180301.11

[87] Ghernaout, D. (2019) Electrocoagulation Process for Microalgal Biotechnology: A Review. Applied Engineering, 3, 85-94.

[88] Ghernaout, D., Benblidia, C. and Khemici, F. (2015) Microalgae Removal from Ghrib Dam (Ain Defla, Algeria) Water by Electroflotation Using Stainless Steel Electrodes. Desalination and Water Treatment, 54, 3328-3337.

https://doi.org/10.1080/19443994.2014.907749

[89] Bibby, K., Aquino de Carvalho, N. and Wigginton, K. (2017) Research Needs for Wastewater Handling in Virus Outbreak Response. Environmental Science \& Technology, 51, 2534-2535. https://doi.org/10.1021/acs.est.6b06492

[90] Diemert, S. and Yan, T. (2019) Clinically Unreported Salmonellosis Outbreak Detected via Comparative Genomic Analysis of Municipal Wastewater Salmonella Isolates. Applied and Environmental Microbiology, 85, e00139-19.

https://doi.org/10.1128/AEM.00139-19 